УДК 811.111. $456-12$

DOI https://doi.org/10.26661/2414-1135-2021-82-16

\title{
ЗІСТАВНИЙ АНАЛІЗ ФРАЗЕОЛОГІЧНИХ РЕАЛІЙ В АНГЛІЙСЬКІЙ ТА УКРАЇНСЬКІЙ МОВАХ
}

\author{
Кириллова М. Д. \\ кандидат філологічних наук, доиент, \\ дочент кафедри теорії та практики перекладу \\ Одеський національний університету імені I. I. Мечникова \\ вул. Дворянська, 2, Одеса, Україна \\ orcid.org/0000-0002-7603-4958 \\ marikirillova56@gmail.com \\ Воробйова К. В. \\ старший викладач кафедри іноземних мов \\ Державний університет "Одеська політехніка» \\ пр. Шевченка, 1, Одеса, Украӥна \\ k.v.vorobiova@opu.ua
}

Ключові слова: фразеологічна одиниия, фразеологічна реалія, фразеологічне значення, ідіоматичність, семантична структура.
Стаття досліджує фразеологічні реалії, які представляють найбільш мальовничу і виразну частину словникового складу мови, відображаючи звичаї, традиції народу, згадки про його історію, фольклор. Вони характеризуються подвійним смислом, значення складових слів цих фразеологічних одиниць створюють цілком новий образ. Фразеологічна реалія - це варіативна категорія, пов'язана з процесом переважно бінарного зіставлення мов на лексичному та фразеологічному рівнях. Окремі мовознавці без належних підстав збільшують деякий обсяг фразеологічних реалій, включаючи доцієї категоріїприслів'я. Вони, без сумніву, можуть бути реаліями, але прислів'я як цілісна одиниця через узагальнено-абстрактний характер не має відповідника, співвідносного денотата в позамовній предметній дійсності. Отже, їх не можна зарахувати до реалій. 3 погляду семантики реалії завдяки наявності в їхньому семантичному континуумі метамовної інформації про закріплення за «своїм» мовним колективом збігаються частково 3 діалектизмами. Як і діалектизми, вони надають мовленню певного колориту, формують мовленнєву характеристику літературних персонажів. Але принципова розбіжність між діалектизмами полягає в тому, що географічна інформація реалій пов' язана з позначуваним предметом. Це інформація про специфічні предмети та явища певного географічного ареалу. Місцева маркованість діалектизмів - інформація про специфічні мовні засоби позначення загальновідомих предметів. Як ми переконались, фразеологізми мають своє специфічне фразеологічне значення, яке відрізняється від загальномовного інваріантного значення, по-перше, унікальністю узагальнення свого семантичного змісту, по-друге, вищим ступенем узагальнення. Унікальність фразеологічного значення хоча б одного компонента фразеологічної одиниці зв'язує всі її компоненти в єдине ціле, поза якими воно не існує. 3 погляду перекладацької практики можна виділити явні і скриті реалії. Вони начебто мають відповідники в мові - сприймачі, але співвідносні денотати в позамовній дійсності дуже відрізняються між собою, тому беззастережна субституція їх позначень, що мають різну художньо-стилістичну наповненість, може спричинити низку додаткових труднощів, пов'язаних із культурологічною розбіжністю. 


\title{
COMPARATIVE ANALYSIS OF PHRASEOLOGICAL REALIA IN ENGLISH AND UKRAINIAN LANGUAGES
}

\author{
Kirillova M. D. \\ Candidate of Science in Philology (PhD), Associate Professor, \\ Associate Professor at the Department of Theory and Practice of Translation \\ Odesa I. I. Mechnikov National University \\ Dvoryanska str., 2, Odesa, Ukraine \\ orcid.org/0000-0002-7603-4958 \\ marikirillova56@gmail.com
}

Vorobiova K. V.

Senior Lecturer at the Department of Foreign Languages

Odesa Polytechnic State University

Shevchenko Avenue, 1, Odesa, Ukraine

k.v.vorobiova@opu.ua

Key words: phraseological unit, phraseological realia, phraseological meaning, idiomatic meaning, semantic structure.
The article examines phraseological realia representing the most picturesque and expressive part of the vocabulary of the language, reflecting the customs, traditions of the people, memoirs of their history, folklore. They are characterized by double semantics and the meaning of the constituent words of these phraseological units creates a completely new image. The phraseological realia is a variational category associated with the process of mainly binary comparison of the languages at lexical and phraseological levels. Some linguists without proper grounds increase the volume of phraseological realia including idioms into this category. They, without any doubt, can be realia but an idiom as a whole unit because of a generalized and abstract character does not have a correspondence, a correlated denotatum in extralinguistic subject matter. Consequently, they cannot be referred to the realia. From the semantic view, thanks to the presence of metalanguage information about assigning to "their" speech group in their semantic continuum, realia partly coincide with dialectisms. Like dialectisms, they provide a speech with a certain colour, create language characteristics of literary characters. But, the fundamental discrepancy between dialectisms is that the geographic information of the realia is associated with a signified object. It is the information about specific objects and phenomena of a particular geographic area. Local marking of dialectisms is the information about specific linguistic means of identifying well-known objects. As we were convinced, phraseologisms have their specific phraseological meaning, which differs from its general linguistic invariant meaning, firstly, by the uniqueness of generalization of its semantic content and, secondly, by a higher degree of it. The uniqueness of the phraseological meaning of at least one component of a phraseological unit combines all its components into a single whole, beyond which it does not exist. From the translation point of view there can be distinguished explicit and hidden realia. They seem to have correspondences in the target language, but the correlated denotata in extralingustic subject matter are very different. So the spontaneous substitution of their meanings which have different artistic-stylistic colouring can lead to a number of additional difficulties associated with culturological differences. 
Постановка проблеми. Проблема, що розглядається в цій статті, пов'язана з виділенням характерних рис англійських фразеологічних реалій, їхніх лексичних та семантичних особливостей порівняно 3 українською мовою. Порівняльне дослідження окремих рівнів мов, які належать до різних мовних груп, $\epsilon$ актуальним, тому що дає змогу прослідкувати та виявити спільне й відмінне в рамках макросистем мов та $є$ основою для лінгвістичних узагальнень у плані порівняльної типології.

Інтенсивний розвиток фразеології за останні десятиліття висунув багато різноманітних проблем. 3 одного боку, завданням фразеології є опис фразеологічного матеріалу окремих мов 3 наголошуванням на їхніх специфічних особливостях, з іншого-дедалі більше значення набирає порівняльне вивчення фразеологічних систем різних мов. Порівняльний аспект системного вивчення фразеології становить великий інтерес як для розробки загальної теорії фразеології, так і для вивчення загальних і відмінних ознак досліджуваних мов.

Вивченню фразеології приділяли увагу вітчизняні та зарубіжні лінгвісти: А.Г. Баранов (1993), О.В. Кунін (1996), Ю.А. Зацний (2001), О.П. Левченко (2005), В.Д. Іжченко (2007). Питання семантики знайшло висвітлення в роботах М.Ф. Аліференка (2006), В.П. Жукова (1991), А.М. Мелерович (2001), В.Н. Телія (1996). Стилістичний план фразеологічних одиниць був предметом наукового зацікавлення А.Я. Баран (1999), М.Т. Демського (1994), З.П. Зорівчак (1983), М.I. Мостового (1993). Отже, в мовознавстві інтенсивно досліджуються найрізноманітніші питання фразеології в iï сучасному стані та в історичному розвитку.

Метою статті $\epsilon$ розкриття семантичного аспекту англійських фразеологічних реалій порівняно з їх українськими відповідниками, механізму ïx творення та визначення історико-етимологічної основи фразеологізмів цього типу.

Методи дослідження. Задля вирішення поставлених завдань використано описовий метод із метою інвентарізації та виокремлення ознак аналізованого фактичного матеріалу, а також власне лінгвістичні методи: зіставний та метод компонентного аналізу.

Результати дослідження. Предметом фразеології як науки $є$ дослідження природи фразеологізмів та їхніх ознак, а також виявлення закономірностей функціонування їх у мові.

Фразеологізми заповнюють лакуни в лексичній системі мови, що не може повністю забезпечити найменування пізнаних людиною нових сторін дійсності, і в багатьох випадках є єдиними позначеннями предметів, властивостей, процесів, станів, ситуацій і т.д. Варто також мати на увазі, що «саме найменування - це не тільки процес позначення денотата, але й процес пізнання» [1, с. 21]. Фразеологія - це скарбниця мови. У ній відтворені життя, історія народу, його культура та самобутність. Англійська фразеологія дуже багата, в неї багатовікова історія. Крім суто національних фразеологізмів, в англійській мові є також запозичені або інтернаціональні фразеологічні одиниці (далі - ФО).

Фразеологічна реалія - це варіативна категорія, пов'язана з процесом переважно бінарного зіставлення мов на лексичному та фразеологічному рівнях. Окремі мовознавці без належних підстав збільшують деякий обсяг фразеологічних реалій, включаючи до цієї категорії прислів'я. Вони, без сумніву, можуть бути реаліями, але прислів'я як цілісна одиниця через узагальнено-абстрактний характер не має відповідника, співвідносного денотата в позамовній предметній дійсності. Отже, їх не можна зарахувати до реалій.

Te, що реалії виникають у загальнонародному процесі словотворення, підкреслює дефініція Я.І. Рецкера: «Реалії - це слова, що позначають предмети, процеси і явища, характерні для життя i побуту країни, але не відрізняються науковою точністю визначення, властивою термінам» $[9$, с. 50].

Значним поступом в опрацюванні реалій в українському перекладознавстві $\epsilon$ праці В. Коптілова, який називає реаліями слова, що означають предмети та явища, не відомі мові перекладу [5]. 3 цього твердження випливає той факт, що слова можуть бути реаліями в одній мові, але не бути такими в іншій. Наприклад, у Великобританії, як i у нас, $є$ проїзні квитки, а у США їх немає. Отже, стосовно американського варіанту англійської мови наш «проїзний квиток» - реалія, а стосовно британського варіанту - ні.

3 погляду семантики реалії завдяки наявності в їхньому семантичному континуумі метамовної інформації про закріплення за «своїм» мовним колективом збігаються частково 3 діалектизмами. Як і діалектизми, вони надають мовленню певного колориту, формують мовленнєву характеристику літературних персонажів. Але принципова розбіжність між діалектизмами полягає в тому, що географічна інформація реалій зв'язана з позначуваним предметом. Це інформація про специфічні предмети та явища певного географічного ареалу. Місцева маркованість діалектизмів - інформація про специфічні мовні засоби позначення загальновідомих предметів.

Вживається у філологічній літературі і термін «діалектні реалії». Його розуміють подвійно, позначаючи ним слова, що називають предмети і явища вузького ареалу, або ж діалектні регіональні назви для предметів чи уявлень загальнонародних. Якщо порівняти часові реалії «на Івана Купала» та «на зільського Йвана», то семантика їх конвергентна: вони позначають одне 3 найпоетичніших календарних дійств, що веде відлік із 
давніх-давен. Наші далекі предки в такий спосіб возвеличували розповінь літа, оспівували розквіт природи. Але щодо узусу ці вирази дивергентні: вислів «на Івана Купала» поширений по всій Україні, а «на зільського Йвана» - вираз діалектної окресленості, відомий лише в Гуцулії, де колись існувало повір'я, що король Гуцул будиться від зачарованого сну один раз на сім років, якраз у день зільського Йвана. Оскільки англомовний світ такого свята не знає, хоч і має в календарі St.John the Baptist's Day (24 червня), то в українсько-англійському бінарному зіставленні часове позначення селянського календаря «на Івана Купала» - загальнонародна реалія, а «на зільського Ивана» - реалія діалектна. Як і всі діалектизми, реалії такого характеру - лінгвостилістична категорія. У художньому тексті вони відразу набирають додаткових смислових і естетичних відтінків, різко контрастують із літературно-нормативною організацією тексту, а тому, очевидно, стають значною мірою промовистими, значущими.

Найчастіше дослідники вдаються до предметної, зовнішньої, позамовної класифікації реалій. Із перекладознавчого погляду доречно провести поділ реалій в історико-семантичному та структурному планах [4].

3 історико-семантичного погляду виділяються:

1) власне реалії (за наявних референтів): укр. коломийка, трембітяр, постоли, яворівка, коливо, китайка, перебудова, гласність; англ. а baby-sitter, Boxing Day, the Central lobby, Poppy Day, Halloween, Harley Street doctor, a gifted child («у США особливо здібна дитина, для якої, 3 дозволу батьків, розробляється спеціальна шкільна програма») та ін.;

2) історичні реалії - семантичні архаїзми, які внаслідок зникнення референтів входять до історично дистантної лексики. Крім національного, для них характерний хронологічний колорит: укр. щезник, смерд, копний майдан, свячений, згінні дні, медведиия («група жінок, що, переодягнувшись, ходила по селу під час косовиці»), зелені «опришки», niдбрехач («другий сват у давніх українських весільних обрядах»), тарниия («дерев'яне сідло гуцулів»); англ. the Black and Tans («чорно-руді» - англійські каральні загони в Ірландії в 1920-1923 pp.), a priest's hole («іст. «нора», пристанище священника; таємна кімната, звичайно в церкві або в замку, де переховувалися католицькі священники в Англії під час переслідування католиків») та ін.

У структурному плані виділяються:

1) реалії-одночлени: укр. вечорниці, криничар, денцівка, кобзарювати, валило; англ. a sheriff, a threepence, a maypole («травневе дерево»-«стовп, прикрашений квітами, різнобарвними прапор- цями, довкруги якого танцюють у першу неділю травня у Великобританії») та ін.;

2) реалії-полічлени номінативного характеру: укр. курна хата, разовий хліб, троїста музика, братська могила, дзвінкова криниця («назва спеціальної радіопередачі про народну пісню»); англ. a banana split, St. Valentine's Day, a Sussex pudding. a ticket day, a toffee apple, a soap opera, garden seats, a means test man та ін.;

3) реалії-фразеологізми: укр. лоби забрити, коло печі поратися, дбати про скриню, стати під вінок, на панщчині бути; англ. to reach the woolsack, to enter at the Stationer's hall та ін.

3 погляду перекладацької практики можна виділити явні і приховані реалії. Останні - це слова типу укр. піч, сорочка («вишиванка»), скриня в українсько-англійському бінарному зіставленні. Вони начебто мають відповідники в мові-сприймачі, але співвідносні денотати в позамовній дійсності дуже відрізняються, тому беззастережна субституція їх позначень, що мають різну художньо-стилістичну наповненість, може спричинити низку додаткових труднощів, пов'язаних із культурологічною розбіжністю. В українсько-англійському бінарному зіставленні до прихованих реалій належить лексема «рушник». У значенні «утиральник» для позначення необхідної в хаті ужиткової речі вона рівновартна рос. «nолотенце», англ. towel. Але в Україні лексемою «рушник» позначають i декоративні рушники, вишивані на тканині, що споконвіку є суттєвим атрибутом повсякденних $\mathrm{i}$ урочистих народних звичаїв, обрядів. 3 опорним компонентом «руиник» в українській мові виникло чимало реалій-етнографізмів, із погляду лінгвістики - фразеологічних одиниць: подавати рушники, повернутися $з$ рушниками.

Фразеологізми мають специфічне фразеологічне значення. I воно не може вважатись лексичним, оскільки слово i фразеологізм е якісно різними мовними одиницями. Фразеологічне значення якісно відмінне від значення лексичного, воно лише спільномірне 3 останнім, але не тотожне йому. Більшість учених, розуміючи специфіку фразеологічного значення, вважають за необхідне виділити його в окрему категорію семасіологіі, закріпивши за ним спеціальний термін $[1 ; 2 ; 10]$. Фразеологічне значення містить не стільки ознаки нині пізнаваних реалій, скільки відношення до вже пізнаного та його оцінку. М.Ф. Алефіренко зазначає, по своєрідність фразеологічного значення, на відміну від значення лексичного, виявляється у «вторинному відтворенні мовної картини світу, збагаченому досвідом інтелектуально-емоційного освоєння носіями мови відповідного «шматочка дійсності» шляхом переосмислення вже існуючих в мові знаків» [1, с. 20]. 
Як ми переконались, фразеологізми мають своє специфічне фразеологічне значення, яке відрізняється від загальномовного інваріантного значення, по-перше, унікальністю узагальнення свого семантичного змісту, по-друге, вищим ступенем узагальнення. Унікальність фразеологічного значення хоча б одного компонента ФО зв'язує всі її компоненти в єдине ціле, поза якими воно не існує.

На те, що у фразеології дуже багато національного, звертали увагу Р.П. Зорівчак, Н.Д. Єрченко. I.В. Корунець виділив в окрему групу національні ідіоми [6, с. 78], які утворюються в будь-якій мові на основі складових частин чи образів, характерних тільки для неї. До цієї групи він зараховує такі ФO: to dine with Duke Humphry, to cut off with a shilling, to accept the Chiltern Hundreds, nередатu куті меду, впіймати облизня, ставити на карб, утерти носа та багато інших.

Н.Д. Петрова стверджує, що «значна кількість англійських ФО є засобом номінації специфічних елементів суспільно-історичної практики». Вона пропонує поділити їх, відповідно до часових та соціально зумовлених ознак семантики, на історичні та сучасні (соціальні, ідеологічні, етнографічні) реалії [8, с. 42].

1. Історичні реалії. Ці ФО позначають різні історичні події, особи, факти: the flower of Chivalry «квіти лищарства»: так називали лицарів із бездоганною репутацією, а саме сера Вільяма Дугласа, лицаря 3 Лідесдейла (1300-1353); the flower of kings - король Apmyp; rose noble - золота монета, на зворотному бочі якої була троянда. До них також зарахуємо: according to Cocker - за всіма правилами (Е. Коккер, 1631-1675, автор англійського підручника арифметики, поширеного у XVIII ст.) (пор. 3 рос. «по Малинину и Буренину»); the Admirable Crichton - учений муж (за ім'ям відомого шотландського ученого XVI ст. Джеймса Крайтона); Hobson's choice - примусовий вибір; або ие, або нічого (за ім'ям Гобсона, власника конюшні в Кембриджі у XVI ст., який зобов'язував своїх клієнтів або брати крайнього до виходу коня, або ж не брати жодного); when queen Anne was alive - за иаря Панька; Jack Ketch - каm (за ім'ям англійського ката XVII ст.): Jack O'Bedlam - божевільний (прізвисько божевільних, яких не можна було вилікувати і яких відпускали 3 лондонської божевільні Бедлама i дозволяли жебракувати); а Joe Miller - заяложений дотеп, жарт (за ім'ям актора Джозефа Міллера, який видав першу в Англії збірку жартів); $a$ Sally Lunn - здобна булочка (за ім'ям жінки-кондитера кінця XVIII ст.).

2. Сучасні реалії. Досліджувані ФО класифікуються на:

а) ідеологічні, що виявляють позиції сучасної культури (flower people «прибічники культу стро- катого одягу» i «загального кохання»), яка могла б замінити матеріальний аспект людського життя (середина 60-х рр.); fat cat-товстосум, який фінансує політичну партію або кампанію; «грочовий мімок»; Cat and mouse Bill - біль, який дає змогу звільнити заарештованих за станом здоров'я;

б) соціальні, що відображають закони розвитку суспільства, офіційний статус людей, їх матеріальне становище, назви професій тощо: great lionпопулярна людина, знаменитість; top dog - господар становища; lion of the season - зірка сезону; a man of straw - людина без будь-яких засобів;

в) етнографічні, які є релевантними для англомовних культур, зокрема, назви мешканців певної території, назви страв тощо: cat's cradle - «мотузочка» - дитяча гра (мотузочку накидають на пальці, як різноманітні фігури); Norfolk turkey «норфольський індик» жартівливе прізвисько уродженця або мешканця графства Норфолк; stag party - «вечірка оленів» - зустріч без жінок (неофіційні, рідше офіційні збори чоловіків, вечір, засідання певної організації).

Національно-культурні семи можуть проявлятися на рівні значення фразеологічного прототипу. Межа між національно-культурними потенціями окремих лексичних компонентів ФО та власне прототипом не завжди чітка, оскільки змінне словосполучення, яке зазнає переосмислення, формується на грунті регулярних значень лексем, інтегрованих у склад ФО (серед них і національно-марковані). Такі утворення можна поділити на природні (в їх основі життєві ситуації, ситуації живої природи, ситуації, що виникають у різних мовах з однаковими значеннями та аналогічною дериваційною базою) та конвенційні, пов'язані 3 історичними, культурними, соціальними властивостями розвитку відповідного народу (вони не мають аналогів у неблизько споріднених мовах).

Цілком очевидно, що велика кількість ФО 3 національним компонентом властива i українській мові. Розглянемо деякі приклади відповідності англійських та українських фразеологічних одиниць. Еквівалентність англійських та українських ФО, що містять застарілі слова, зводиться практично до нуля. Українська ФО на ять та англійська ФО hue and cry, які складаються із слів ять та hиe, котрі не вживаються як вільні лексеми, а також інші ФО, що містять власні назви та назви національних реалій, утворюють більшу частину фразеологічних зрощень. Їх загальне значення $\epsilon$ абсолютно немотивованим, тобто не пов'язаним iз значенням їх складників. Українським немотивованим ФО відповідають англійські дублікати або вільні словосполучення та слова: бити байдики - to twiddle one's fingers; точити ляси - to talk nonsense, сісти в калюжу - to put one's foot into one's mouth, глуха тетеря - a deaf fellow; за пояс 
заткнути - to outdo somebody, намотати на вус to put that in your pipe and smoке it; обібрати як липку - to leece. Відповідно, майже неможливо знайти український еквівалент англійського фразеологічного зрощення: humming and hawing нерішуче топтання на місці; rank and file - рядові люди; waifs and strays - безпритульні; to be at loggerheads with one - не ладнати 3 кимось; in a trice - миттю. Це стосується і ФО з власними назвами: заробив, як заблоцький на милі; пропав, як швед під Полтавою; на безлюдді і Хома чоловік; що вільно панові, то не вільно Іванові; як Сидоpoву козу; Jack and Jill (хлопець та дівчина); Jack in office (бюрократ) та інші.

Сміт визнає, що в англійських ФО «багато гумору, але мало романтики та краси» [9, с. 158]. Зате він із гордістю зауважує, що найчисленнішу та виразнішу групу утворюють $Ф О$, які виражають такі риси національного характеру англійців, як рішучість, непоступливість, готовність боротися до кінця. Серед них такі ФО: to put one's shoulder to the weel- енергійно взятись до роботи; to go through fire and water - пройти крізь вогонь i воду; to die hard - до кінця чинити опір смерті; to nail one's colours to the mast - не відступати.

I хоча англійські ФО містять багато виразів, взятих із народної мови інших європейських країн, все ж за своїм характером, гумором, образами та асоціаціями вони є глибоко національними. Звідки беруть початок усі форми національної мови і національного мистецтва.

Висновки. Отже, проаналізований матеріал дає змогу зробити висновки, що фразеологія - унікальне мовне явище, оскільки ФО властиві всім мовам. Та в кожній мові (як в англійській, так i в українській) вона має особливі форми виразу. Фразеологічне багатство створюється протягом століть як наслідок діяльності колективного народного розуму. У фразеології яскраво виявляються самобутність мови, іiї специфічний колорит, особливості образного народного мислення.

Предметом подальшого дослідження 3 означеної проблематики може бути поглиблений контрастивний аналіз фразеологічних реалій у різних варіантах англійської мови.

\section{ЛIТЕРАТУРА}

1. Аліфіренко М.Ф. Теоретичні питання фразеології. Харків : Академія, 1987. 287 с.

2. Баранов А.Г. Функционально-прагматическая концепция текста. Ростов-на -Дону : Издательство Ростов. гос. ун-та, 1993. 182 с.

3. Ерченко П.Г. Класифікація фразеологічних одиниць. Іноземна фразеологія. 1994. Вип. 107. С. 8-16.
4. Зорівчак Р.П. Реалія і переклад (на матеріалі англомовних перекладів укр. прози). Львів : Вид-во при Львів. ун-ті, 1989. 280 с.

5. Коптілов В.В. Теорія і практика перекладу: Навчальний посібник. Київ : Юніверс, 2002. 280 с.

6. Корунець I.В. Теорія і практика перекладу (аспектний переклад): Підручник. Вінниця : Нова Книга, 2003. 448 с.

7. Кунин А.В. Курс фразеологии соврем. англ. языка: [учеб. для ин. тов. и фак. иностр. яз.] 2-е д., перераб. Москва : Высшая школа, 1996. $381 \mathrm{c}$.

8. Петрова Н.Д. Англійські фразеологічні одиниці 3 націон.-культурологічним компонентом. Іноземна Філологія. 1997. Вип. 110. C. $41-53$.

9. Смит Л.П. Фразеология англ. языка / Пер. А.С. Игнатова. Москва : Учпедгиз, 1989. 208c.

10. Супрун А.П. Семантико-стилістичні особливості фразеологічних одиниць (на матеріалі поетичних творів Максима Рильського) : дис. ... канд. філол. наук : 10.02.01. Миколаїв, 1999. $302 \mathrm{c}$.

11. Баранцев К.Т. Англо-український фразеологічний словник. Київ : Знання, 2005. 1056 с.

12. Медведєва Л.М., Дайненко В.В. Англо-український словник парних словосполучень. Київ : Українська енциклопедія, 1994. 493 с.

\section{REFERENCES}

1. Alifirenko M.F. (1987) Theoretical problems of phraseology [Teoretychni pytannia frazeolohii]. Kharkiv, $287 \mathrm{p}$.

2. Baranov A.G. (1993). Functional and pragmatic text concept [Funkcional'no-pragmaticheskaya koncepciya teksta]. Rostov-na-Donu, $182 \mathrm{p}$.

3. Erchenko P.H. (1994). Classification of phraseological units [Klasyfikatsiia frazeolohichnykh odynyts]. Foreign phraseology. vol. 107. pp. 8-16.

4. Zorivchak R.P. (1989) Realia and translation (based on English translations of Ukrainian prose) [Realiia i pereklad (na materiali anhlomovnykh perekladiv ukr. prozy)]. Lviv, $280 \mathrm{p}$.

5. Koptilov V.V. (2002) Theory and practice of translation: Textbook [Teoriia i praktyka perekladu: Navchalnyi posibnyk]. K., 280 p.

6. Korunets I.V. (2003) Theory and practice of translation (aspect translation): Textbook [Teoriia i praktyka perekladu (aspektnyi pereklad): Pidruchnyk]. Vinnytsia, 448 s.

7. Kunin A.V. (1996) Course of phraseology of Modern English: [Kurs frazeologii sovrem. angl. yazyka: [ucheb. dlya in. tov. i fak. inostr. yaz.]. M: Vysshaya shkola, $381 \mathrm{p}$. 
8. Petrova N.D. (1997) English phraseological units with a national-cultural component [Anhliiski frazeolohichni odynytsi $\mathrm{z}$ natsion.-kulturolohichnym komponentom]. Foreign philology. vol. 110. pp. 41-53.

9. Smit L.P. (1989) Phraseology English language [Frazeologiya angl. yazyka]. Translation by A.S. Ignatova. M.: Uchpedgiz, 208p.

10. Suprun A.P. (1999) Semantic and stylistic features of phraseological units (on the poetic works of
Maxim Rylsky) [Semantyko-stylistychni osoblyvosti frazeolohichnykh odynyts (na materiali poetychnykh tvoriv Maksyma Rylskogo)]: dys. ... kand. filol. nauk: 10.02.01. Mykolaiv, $302 \mathrm{p}$.

11. Barantsev K.T. (2005) English-Ukrainian phraseological dictionary [Anglo-ukrainskyi frazeolohichnyi slovnyk]. Kyiv, 1056 p.

12. Medvedieva L.M., Dainenko V.V. (1994) EnglishUkrainian dictionary of paired phrases [Angloukr. slovnyk parnykh slovospoluchen]. K., 493 p. 